\title{
How Social Will Social Europe Be in the 2020s?
}

\author{
Silvana Sciarra*
}

\section{A. Synergies: Challenges for a New Social Agenda}

Ursula von der Leyen's political guidelines for the next European Commission ${ }^{1}$ place an emphasis on ensuring fair minimum wages within 100 days of her mandate. Differences in minimum wages among Member States of the EU are striking. ${ }^{2}$ Not only do they reflect the state of the economy, they also indicate different traditions in collective bargaining, which are not easy to overcome. Early in 2019, the German labor minister announced that during the German Presidency, in the second half of 2020, a "European legal framework for minimum wages and minimum income" would be launched. In 2014, in response to a European Council's Recommendation, Germany adopted legislation in this field that was issued within the European Semester's procedural framework. Consequently, salaries enter the scene of delicate institutional balances, despite the fact that an EU competence on such matters is explicitly excluded-Article 153.5.

The challenge for the new Commission should consist of proposing synergies among existing measures. This idea can be traced to the Pillar of European Social Rights, ${ }^{3}$ an ambitious policy document encompassing different plans and bringing together different international sources. At a time of serious threats for social rights in the EU, the Pillar recalls relevant provisions of EU primary law-including Article 9 of the Treaty on the Functioning of the European Union ("TFEU"), the innovative "horizontal clause," which should lead to the enforcement of rights and principles enshrined in the Charter of fundamental rights - and refers to labor standards provided for in ILO Conventions and in the European Social Charter. This is noteworthy. A convergence of standards strengthens the floor of fundamental rights and prepares the ground - if necessaryfor the intervention of courts. Synergies are meant to contrast the dispersion of legal guarantees and should reassure disillusioned European citizens, who expect rapid answers. The direction taken in the new Directive on transparent and predictable working conditions in the European Union is reassuring, because it bases the first binding legal measure on Principles 5 and 7 of the Pillar, which takes into due account the CJEU's case law on criteria to establish the notion of a worker, in view of expanding the scope of previous secondary law and includes those with unpredictable working patterns and non-standard forms of employment. ${ }^{4}$

Programs to support fair wages are an absolute priority. Principle 6 in Chapter II on Fair Working Conditions adopts a language familiar to constitutional principles across Europe. It mentions the adequacy of minimum wages and finalizes it to the satisfaction of essential needs

\footnotetext{
${ }^{*}$ Judge at the Constitutional Court of Italy.

${ }^{1}$ Ursula von der Leyen, A Union that strives for more: My agenda for Europe (July 14, 2019).

${ }^{2}$ Thorsten Schulten \& Malte Luebker, WSi Minimum Wage Report 2019: Time for Substantial Minimum Wage Rises and a European Minimum Wage Policy (46th ed. Mar. 2019).

${ }^{3}$ The European Pillar of Social Rights in 20 Principles, Eur. COMM'N, https://ec.europa.eu/commission/priorities/deeperand-fairer-economic-and-monetary-union/european-pillar-social-rights/european-pillar-social-rights-20-principles_en (last visited October 23, 2019).

${ }^{4}$ Directive 2019/1152, of the European Parliament and of the Council of June 20, 2019 on Transparent and Predictable Working Conditions in the European Union, 2019 O.J. (L 186) (EU).
} 
of workers and their families. This is not a mere program, but should be seen as a prescriptive discourse, not to be postponed. Wages have been at the core of many constitutional court decisions dealing with austerity measures. Wages are connected to price instability and to programs against poverty: They are pivotal to guaranteeing the dignity of persons.

Principle 14 in Chapter III on Social Protection and Inclusion deals with minimum income, the other side of the coin, namely the sufficiency of resources for those who have none, or who may need incentives to be reintegrated in the labor market. Synergies in these two fields are possible, and indeed necessary, in view of promoting coordination at a European level and creating a common ground for actionable rights.

Criticism has been raised because social partners were marginalized within the European Semester. The Tripartite Social Summit too was not invigorated and given wider competences on related economic and monetary issues. Challenges are incumbent and might, in the long run, even require a reform of Article 152 of the TFEU. Nevertheless, the social partners should echo, in all relevant circles, the deficiencies of the Summit as it stands.

\section{B. Inequalities: Challenges for the Social Partners}

Social dialogue is a peculiarity of the "European social model," inasmuch as it has institutional relevance in the TFEU. The "model" has been severely shaken by various events, mainly having to do with a progressive decline in the visibility of European organizations representing labor and businesses. A parallel decreasing membership at a national level and a reduced coverage of collective agreements ring another worrying bell. ${ }^{5}$ National governments have, in some countries, obstructed the communication with the social partners and acted for "dis-intermediation." Choices of this kind are in sharp contrast with European constitutional traditions and with EU primary law.

It is true, though, that awareness across the EU should be circulated on how the social partners act in their many capacities. For example, in recent times they have not been active in promoting legislation through framework agreements, as for Articles 154 and 155 of the TFEU. The longsighted imagination displayed by Jacques Delors in his 1985-1995 Presidency of the Commission made them co-protagonists in the law-making process, but they are not exercising this prerogative as much as they should. This is a challenge to consider very closely and an exercise that should restart, together with a much-expected upsurge of legislative initiatives in the social field.

Social partners should embrace the fight against inequalities, which have been dramatically spreading in the EU. This distortion has been visible even before the outbreak of the economic and financial crisis, as a consequence of major differences in wages and working conditions in countries of the enlargement, compared with richer economies.

Mobility of workers is often at the origin of inequalities; the revised Directive on posted workers addresses these issues. ${ }^{6}$ Furthermore, a regulation has been recently adopted, establishing a European Labor Authority (ELA), to tackle undeclared work and to promote fairness and trust in the market, whenever the mobility of workers is at stake. ${ }^{7}$ The two measures are complementary: Close supervision should also come from the social partners, who must feel responsible in combating unfair practices in the internal market, enhancing equal treatment in comparable working conditions.

\footnotetext{
${ }^{5}$ Torsten Müller et Al., Collective Bargaining in Europe: Towards an Endgame Vol. 1 (2019).

${ }^{6}$ Directive 2018/957, of the Parliament and of the Council of June 28, 2018 Amending Directive 96/71/EC Concerning the Posting of Workers in the Framework of the Provision of Services, 2018 O.J. (L 173) 16 (EU).

${ }^{7}$ Regulation 2019/1149, of the European Parliament and of the Council of June 20, 2019 Establishing a European Labor Authority, Amending Regulations (EC) No 883/2004, (EU) No 492/2011, and (EU) 2016/589 and Repealing Decision (EU) 2016/344, 2019 O.J. (L186) 21 (EU).
} 
ELA's provisions are addressed to third-country nationals legally resident, or long-term residents, according to EU law regulating their mobility-like number 13. This is a most urgent challenge, but ELA will not be in operation immediately. There should be ways to anticipate monitoring on labor mobility and indicate existing best practices. Solidarity requires, in these cases, a trans-border dimension and should be encouraged, experiencing all forms of coordination in collective bargaining. The Regulation-in number 11-aims at supporting the enforcement of universally applicable collective agreements in accordance with Member States' practices. This is a clear challenge for the social partners, in gaining credibility among their members and guaranteeing the enforceability of collective agreements.

Inequalities are also created by uneven opportunities offered to jobseekers. Cedefop, the specialized agency for vocational training, is active in matching labor market demands with the offer of adequate skills, but experiments and concrete results in this direction are not always satisfactory. Coordination of national labor markets is not an easy task and the mobility of workers seeking employment only becomes possible for a minority of them.

The European Network of Public Employment Services (PES) was assigned the task to promote active employment policies, within the Europe 2020 agenda. A Council Decision addressed to Member States - 573/2014/EU_-marked a return to hard law and tackled the potentialities of coordination through "benchmarking" and "benchlearning" indicators, leaving to the Commission's delegated acts the option to change them and make them adaptable to different needs. Along similar lines, the Council adopted the Recommendation on Youth Guarantee to face the problem of NEETs, young people in neither employment, education, or training.

ELA will operate in coordination with PES and will replace the Commission in coordinating the European Network of Employment Services (EURES) — established by EU Regulation 2016/58 - the latter active in promoting interaction among private and public employment agencies. Synergies, once more, are invoked.

The challenge is to stabilize all initiatives addressing unemployment, not identifying them anymore as emergency measures. Long-lasting projects of inclusion in labor markets are faced with challenges of permanent learning and must be supported by selective incentives. Should all these challenges be discussed in the Social Summit in a more constructive way and be followed by the vigilant eyes of the social partners? Should national governments feel the pressure of business and labor, operating in close connection with their European "umbrella organizations?"

\section{Challenges to Solidarity: Policies of Integration Come First}

A most unsettling discontinuity in the European tradition of solidarity is the marginalization of immigrants and refugees. Most measures appear ineffective, and so are the attempts to enhance solidarity. Back in 2017, the social partners signed an agreement on European partnership, offering opportunities for refugees to integrate in the labor market. ${ }^{8}$ The Commission provides support for active labor market policies, triggering training facilities, in order to foster talents and skills that third-country nationals carry with them. It is clear, though, from the narration of suffering and exclusion, that this instrument is insufficient. The challenge should consist in reproducing partnership agreements at a decentralized level, including local authorities in view of adapting training to different needs of local economies. Traditional—and often very qualified—skills that refugees can retrieve from previous working experiences should become a collective patrimony of local communities.

The prerequisite to all of this is funding. The signatory parties to the agreement refer to "relevant EU funds" to support integration. The long and complicated negotiations for the

\footnotetext{
${ }^{8}$ European Commission, A European Partnership for Integration OfFering Opportunities for Refugees TO INTEGRATE INTO THE EUROPEAN LABOUR MARKET (2019), https://www.etuc.org/sites/default/files/circular/files/ signedintegrationpartnership_0.pdf.
} 
Multiannual Financial Framework 2021-2027 have begun. Relevant funds are ESF+ and AMF. It is the responsibility of the new Commission to set a transparent road map and indicate priorities, which should meet the most urgent and dramatic needs of the weakest. Discussions on the use of EU funds are recurrent and show how crucial it is to include local communities and regional authorities both in the allocation of funds and in the management of projects. It has been suggested that a percentage of funds, managed at EU level, should be reserved to civil society organizations and local actors. ${ }^{9}$ Apart from the simplification of procedures, the key for opening opportunities should be vicinity of the institutions in providing inclusion. This should not clash with State competences on migration policies. Challenges are immense and they are related to wider political responsibilities. They are challenges for all European citizens and should be reflected in a reliable and inclusive social agenda for the EU.

\section{Challenges for Policymakers: A European Unemployment Scheme}

Controversial points of view among European policymakers characterize ways to tackle unemployment. Soft law mechanisms put in place in 2000, as part of the memorable Lisbon strategy, did not prove to be sufficiently incisive. The initial enthusiasm for deliberative practices, which should have promoted mutual learning among national administrations, was obscured by the scarce results achieved. Consequently, the move to active employment policies saw the return on the scene of hard law measures, as pointed out before.

An additional step to re-politicize deliberations whenever essential needs of European citizens are at stake goes into the direction of supporting Member States experiencing significant increases in the rate of unemployment, introducing a European Unemployment Scheme, as a stabilizer in the event of adverse economic shocks. Ideas have been aired for some time in academic circles and promoted by the Commission. ${ }^{10}$ Such a scheme was part of the 2012 Commission's proposals to strengthen the social dimension of the EMU and counterbalance the disaffection experienced by countries undergoing severe economic difficulties. The main challenge regards the regulatory technique suitable for this proposal. Harmonization could be problematic because of differences in Member States' rates of unemployment, wages to be referred to, and duration of the benefit. This is not an insurmountable challenge, however, and may in fact lead policymakers towards innovative experiments well beyond the mere allocation of economic subsidies.

A survey has been issued to investigate the level of public support to a European initiative, which should be based on risk sharing-taking into account specific needs of the unemployed and accompanying temporary subsidies with active measures to seek employment. ${ }^{11}$ This open ground for discussion implies, once more, that policies should be delivered in synergy to each other, framed within a dynamic vision of labor market reforms.

\section{E. Teaching European Social Policies and Adjudicating on Social Rights: A Personal Appraisal}

For a long time, social policies have been a contested terrain in the overall development of European law. They have been compressed because of frequent unanimity votes requested in the Council and balanced against other impellent priorities, in order to guarantee market

\footnotetext{
${ }^{9}$ European Council on Refugees and Exiles, Promoting Socio-Economic Inclusion of Migrants and Refugee in THE NeXT EU BudgET (2021-2027) (2019), https://www.ecre.org/wp-content/uploads/2019/02/PICUM-ECRE-Policy-PaperPromoting-socio-economic-inclusion-of-migrants-and-refugees-in-the-next-EU-budget-December-2018.pdf.

${ }^{10}$ Miroslav Beblavý, Gabriele Marconi \& Ilaria Maselli, A European Unemployment Benefit Scheme: The Rationale and the Challenges Ahead (2017).

${ }^{11}$ Frank Vanderbroucke et Al., Risk Sharing When Unemployment Hits: How Policy Design Influences Citizen SUPPORT FOR EUROPEAN UNEMPLOYMENT RISK SHARING (EURS) (2018), https://pure.uva.nl/ws/files/30755292/_327_eurs_ policy_report_final_1.pdf.
} 
efficiency. As a consequence of an alleged idiosyncrasy of all such matters, strictly interconnected with economic and monetary policies and yet marginalized in the political actions, there has been a tendency not to place European labor and social law very high in academic curricula.

My personal experience as an academic who had the opportunity to teach European social law allows me to oppose such marginalization. The challenge for the 2020s, addressed to universities and academic institutions, is to train young people in social law and social policies. It is crucial to disseminate teaching in these areas and link them up to other disciplines, in order to build coherent and overarching curricula. This challenge is for the expansion of a European social culture, grounded on principles of social justice and supported by the understanding of what social rights mean to each citizen and how they relate to everyday life.

\section{F. Conclusions}

In my experience as a Constitutional Judge, I have strengthened the idea that challenges to social rights need a cultured approach to the long and often difficult history lying behind their consolidation in constitutional traditions. Balancing them against other rights means adjudicating on their adequacy and proportionality; it means inquiring into the essential needs of each individual and evaluating the role of organized groups entitled with the exercise of collective rights. This brings about the reconsideration of solidarity, in its many connotations: Not only a rhetorical concept, but a constitutional project, grounded in the law of Member States and prioritized in the EU Charter of fundamental rights - an impellent command for Governments, civil society, and citizens. ${ }^{12}$

Challenges to keep continuity in constitutional traditions and the rule of law should be met unequivocally during the 2020s, spreading the culture of social rights among the youngest generations.

\footnotetext{
${ }^{12}$ Silvana Sciarra, Solidarity and Conflict: European Social LaW in Crisis (2018).
} 